にるの接研も

お葸思連究シシ

てわ展関等 ユヴ

も沓開し、゙劣

説るにて広アイ

い。おい範イツ

てといる囲ツア

は

じ

い市て点な

め

る の 、它域はミ

ら多

で彼ヴ思捊哲

あ彼占思い学贻

。生イの思研

つの命全想究产

ま畏、学展倫

、敬の把開理の

シ の思握 し 思思

ユ 理想るい史内

少核こる的容

イ哲灾市研の

ツ哲はに学統

ア学的早立あ神的

に的生ちあ神性

の展のだる。学格

生開畏吕ま聖を

のる敬るた壁畫ら

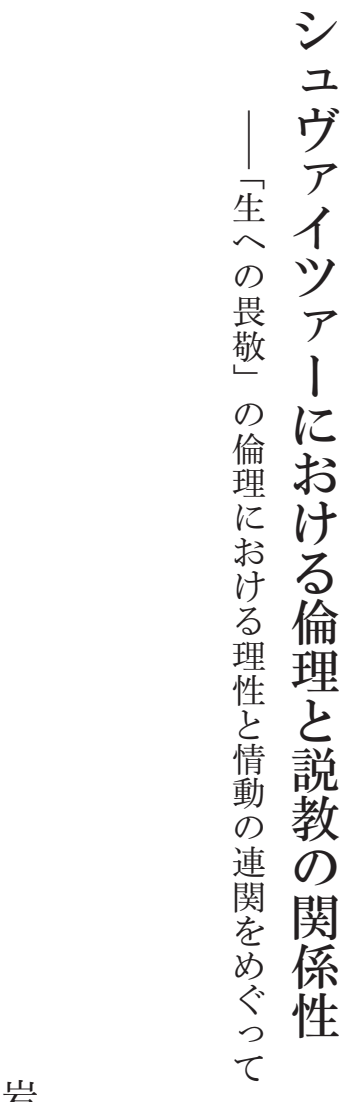

倫な゙壆隹光研究る

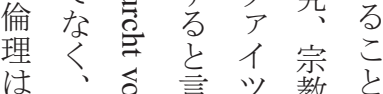

理説气言ツ整は

論教导文|学容

哲教5 5 。思研易

岩

井

謙

学会し想究は

的に名研 な

思竗のし究比い

太

る理多実宗と

と実に彩践教い

郎

実践存なと論ら 


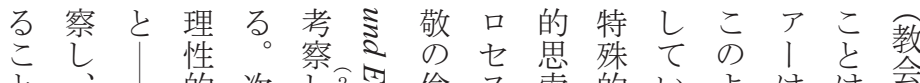

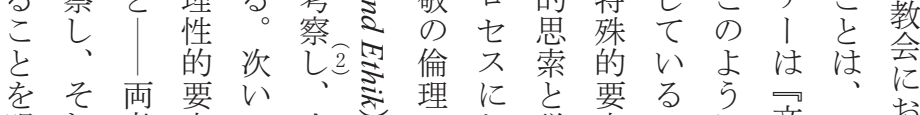
明机者素で生さ市説素のに文ひ掠 確にがと、へに構け教っで、化いけ 化よ構情二の㧧る築るに手あシ哲てる すつ造動章畏けの理おリるュ学は説 るて 的的で敬るた性い驾少等教 シに類票は、のシめ的て、ト、ア寺ジ

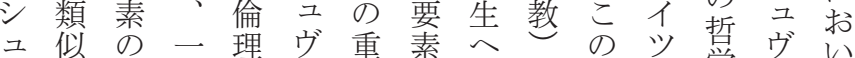
ヴし動章○ア要とのと䦗ア学ア的アて アて 的で高イな情畏の題门的イ著 イい連考次ツ概動敬関は著 ツ㤫 ツる関察のア念的の係、生を作了さ アこがし楽!で要倫をジへ叙!れ

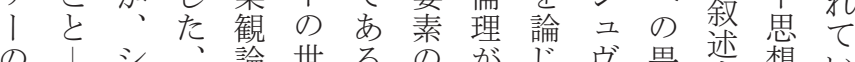
の|シ、論世る、の省じヴ畏述想い 思 ユ 素的界関どる ア 敬る のる 想をヴ朴世観思係の際イののる 全の が口アな界の惟性よにツ倫前体で 単説 1 楽 観問概を考名了理前像 に教 ツ 観題念分に重! の生考生 そ集ア論が空析連要に哲生考へ れ|的有!認主関な掠学の察の

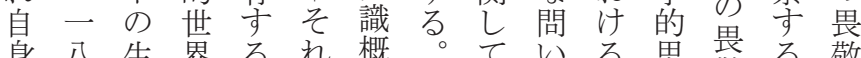
身八生界るれ概。ている思带る敬 で九へ観理と念具いで生索敬たの

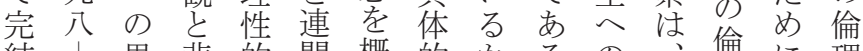
結| 畏悲的関概的加るの倫に理 し 一 敬 観 要し 観にをと畏教理有を て九の論素たし、論言敬会を教益め

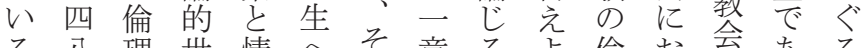
る八理世情へそ章る倫お会ある のにに界動の机でたら。理け説る哲 です関観的畏をはめ。要满学

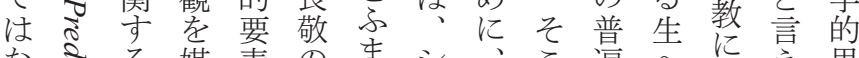

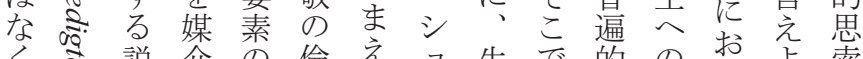

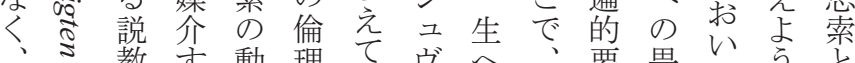

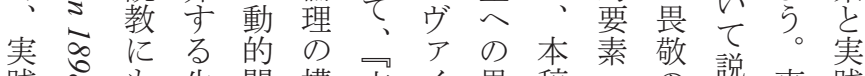

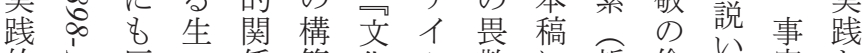
的它反系築化 少敬に哲倫て実と

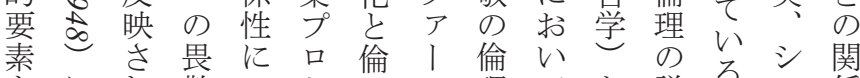
をに机敬つセ理の理てと説るすュ係 有扮てのい岕生の洪々教で占性

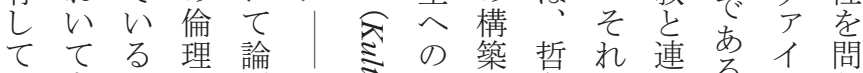

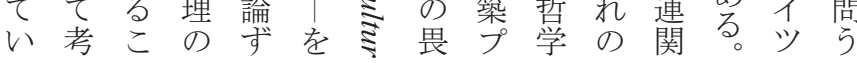


おと力あ訳っる

てさ理がの

はれ性、よ

認 5 的シ

識る要 ユに

作 采思

用のをイ惟

とド司ツ作

しイるア用

てツ作|は

論語用は

じ唔事

るす、思実

のなシ惟を

でわユの客

あち ヴ 働 観

るマアき的

認导少合把

識兰了理握

の匛|的 守

作と譙る

とを識能と

の 品文方去

対芯称の旨

にるる意守

打をののる

い、でみ

て前あに合 者 る 限理

思に。定的

惟お彼し推

のいはて 論

作て日

用は本な力

の思語い。

性の扮む性

に作以し的

つ用てろ要

いとは、素

てしど合を

シ 5 的含

工後专推导

ヴ者理論 の

アに性能で

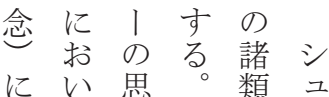

は全つて惟そ型型

事く い簡 概の去了

実二て 笚念際自イ

に般詳につ究己

つ的細検認彼完了

いにに討識は成!

て言考し概思のは

の え察て念惟倫口

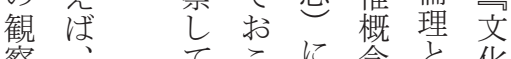

察てこに念と化

に思いらつ累献亡

扮惟

いは

て 熟

秩 考

序 $\frac{9}{8}$

ऽ゙ る

ること化生要型て

な、認身倫

いて 識の理

彼、概 倫理

は遺念理に

彼文年重類 い

た忠愉の視を寺倫

めこ: 惟 倫 畏る 導思

に名働里敬る。蒠

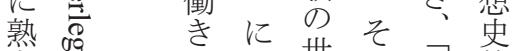

考官

于.

万色 に

の打界こ生的

重以界で生分

要 て 観

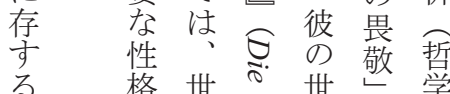

格世宁世敂学

に界㽦界の史

認 つ 観 京 観 倫 的

識 いの壳の理考

にて 構 ミ構|察

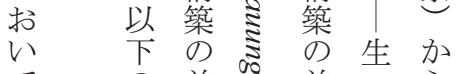

て $の$ 前

\& よ 提 す 提 の世

熟 5 と思亡畏

考になる゙し 敬 観

は 言るミ゙てのの

働 5 思 ※ 世諸

い。惟ざ シ 界類

て 概 ミ ュ 観 型

\begin{tabular}{lll|l} 
る & 念 & の & ヴ \\
る & 神
\end{tabular}

る。認た $な$ を 秘

私識 ミ $ミ$ 構 主

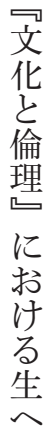

の

畏

敬

の

倫

理

亡

界

観 


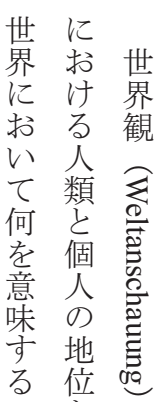

のと使と

? 命 は

私つ 吕。

たて社

は展会

世開

界 寸

にる 。

小思想总

てのき

何総と

欲杂個

す あ 吉

の。、

$\begin{array}{lll}\text { 力 } & \text { 私 } \\ ? & \text { の }\end{array}$

私き本

たて質

ちいと

はる目

世社的

界会に

に掠つ

拉よい

いびて

て私、

何自ま

期 法世

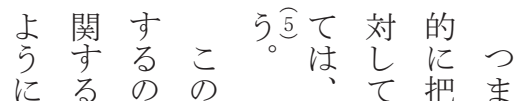

5 思 守

主惟る シ

体作よ工

は用ら尚

のなア

問 特 仕 イ

わ性方 ツ

によ用

沶 50

けな重

る問 要

世いな

界 力 特

観 ら 性

の シ は

問 ユ、

題 ヴ 私

にアた

つ

いツが

てア生

検 证

討はの

乙生 意

て 味

みのを

よ 畏 問

亏。敬

シ倫と

工 理

ヴを自

了構

令築 亡

アる界

は の

世 あ 関

界る 係

観 。性

に次 牲

に の

てそ 以

とそい

下溥存
れを

る ।

対私観は

象た察

にち 守 認

関 がる 識

与 自 主 作

せ主华

ざとはの

る世観 特

を界察徴

えとさを

なのれ

い関る私

仕係対た

方性象ち

にをかが

お主 ら外

以体影的

て 的響 事

自にを実

己洞受

亡察け科

世守な学

界る以的

と態よ事

の度 う実

関にな

係見認知

性る識覚

がの|等

省で

察あにを

さる看主

れ。取観

るそし!

とこ、客

言にそ観

えおれ四

よいに式
の ア

問 認 |

い識泣

にに以

従打市

事いの

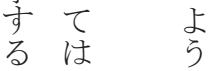

限、に

り昷古

思は

惟 存

そ 在

れに

自 対

身 L

何て

加客

主 観

体 的

的な

で 考

あ、察

る出を

る。

思

惟

は

そ

が

世

界

に

対

क

る

私

の

関

係

に

r 


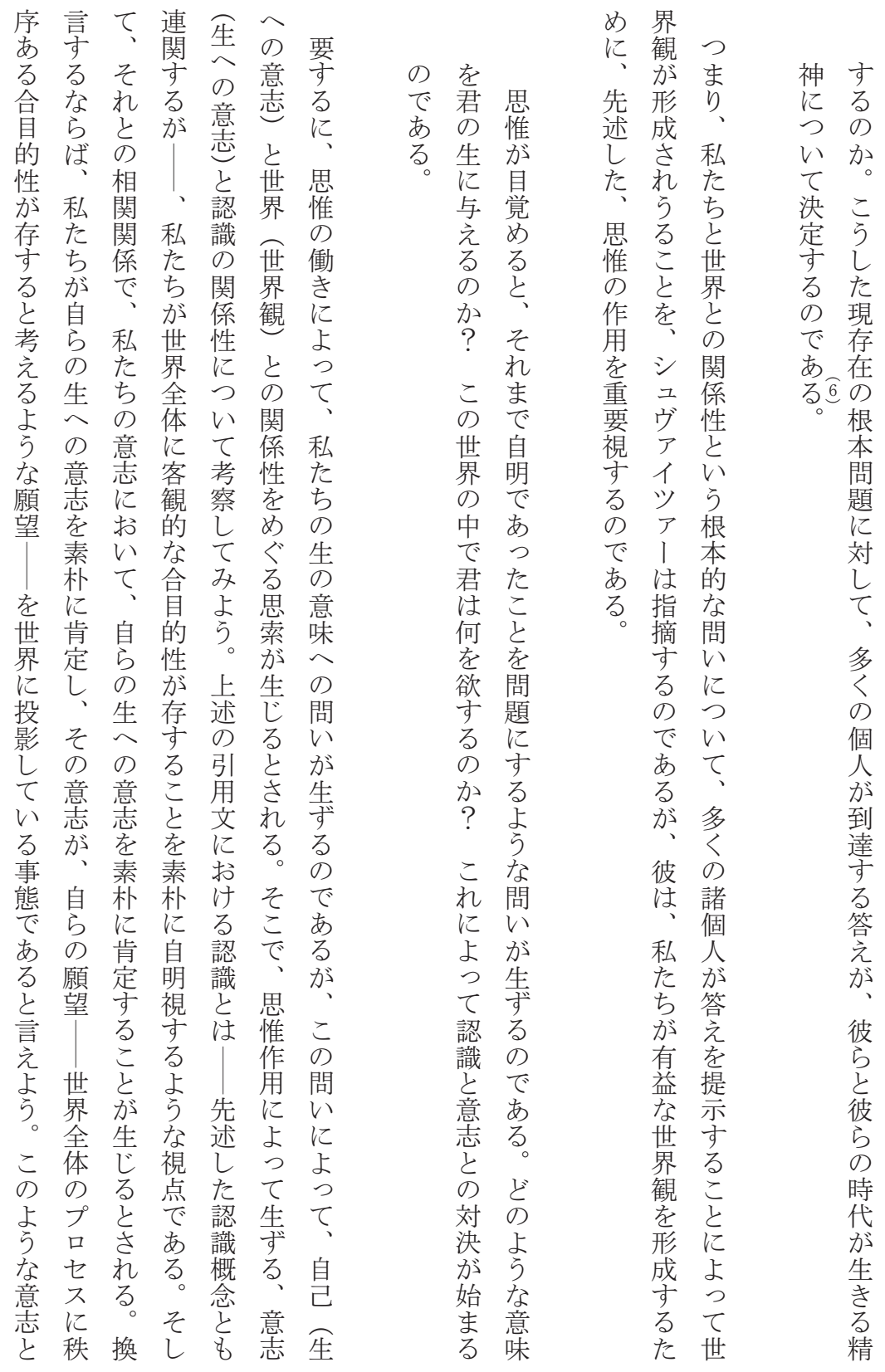


よこ世 世

○界生

てが人命

基で生 観

礎き肯 と

づる。定世

け。之界

ら 之倫 観

れれ理の

るがに相

こ無固 互

と批執関

を判守係

願なるを

ら思こ思

に惟と惟

もに 驾

加現 $\ominus$

かわ白

われ』 に

らる䆑守

导仕总る

命できき

観はきに

は生 思

認命吉惟

識観志忧

加世官認

生界导識

るに 断

の依志念

は拠声

なし こ ठ

いて

生な突

命い権筧相

は生互导

自命に

己観 結

自はび

身認つ

の識け

上にると
下世 黄で対てし確てれ自意認

の界世界京い信そる。ら志識

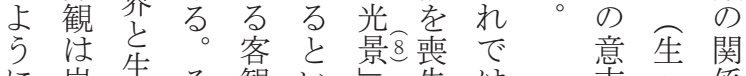
に崩生そ観い京失は志心係 自壊否し的うをしのの の の 危定て な合り 呈て な 現意よ 思機とこ目のてま私をを学 想に称の的まいらた成 を瀕守よ性まるのち 察よ立

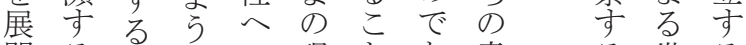
開る。なの現とあ意るる る すとこ意素実をろ志を界世

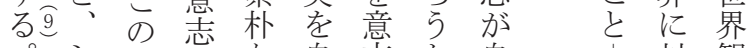
シよとな自志加自就

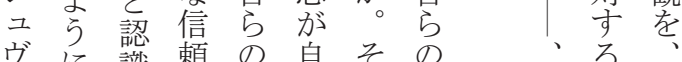
ヴア識頼の鼻そ生筧れ現 世 願 シ イ観関崩へ守は実界望 ユ ツ論係壊のる、全のヴ 了的に意加私省体投了 |世志らた察少影イ は界っそがでち守っ プはツ 考観てれ認あ孞る え註成と識る営と私! て私成連立。导きたは いた 立関るつ世芯ち楽 るち るし点ま界、有が観 のにるたにりに世自論 で突世界生、打界方的 あき界去シあい全合の世 るさ観のュるて体目意界 が、を意ヴ生はの的志観 こらシ 志ア 命 只 プ

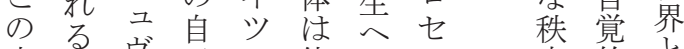
事こヴ方ア他の文序的と 態々ア否|意に次生

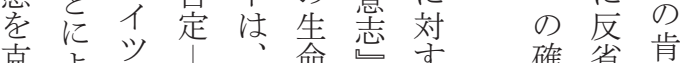
克よツ命怘確省肯

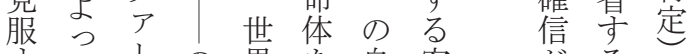
守てはの界を自客加る る、は要全犠㞯観色こ機と称

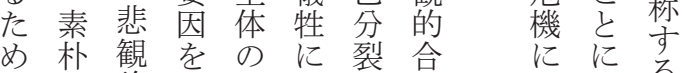
にな論見プしの自瀕よる。 楽的て $て \tau$ 劇的等 0 彼観世界 る

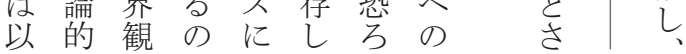




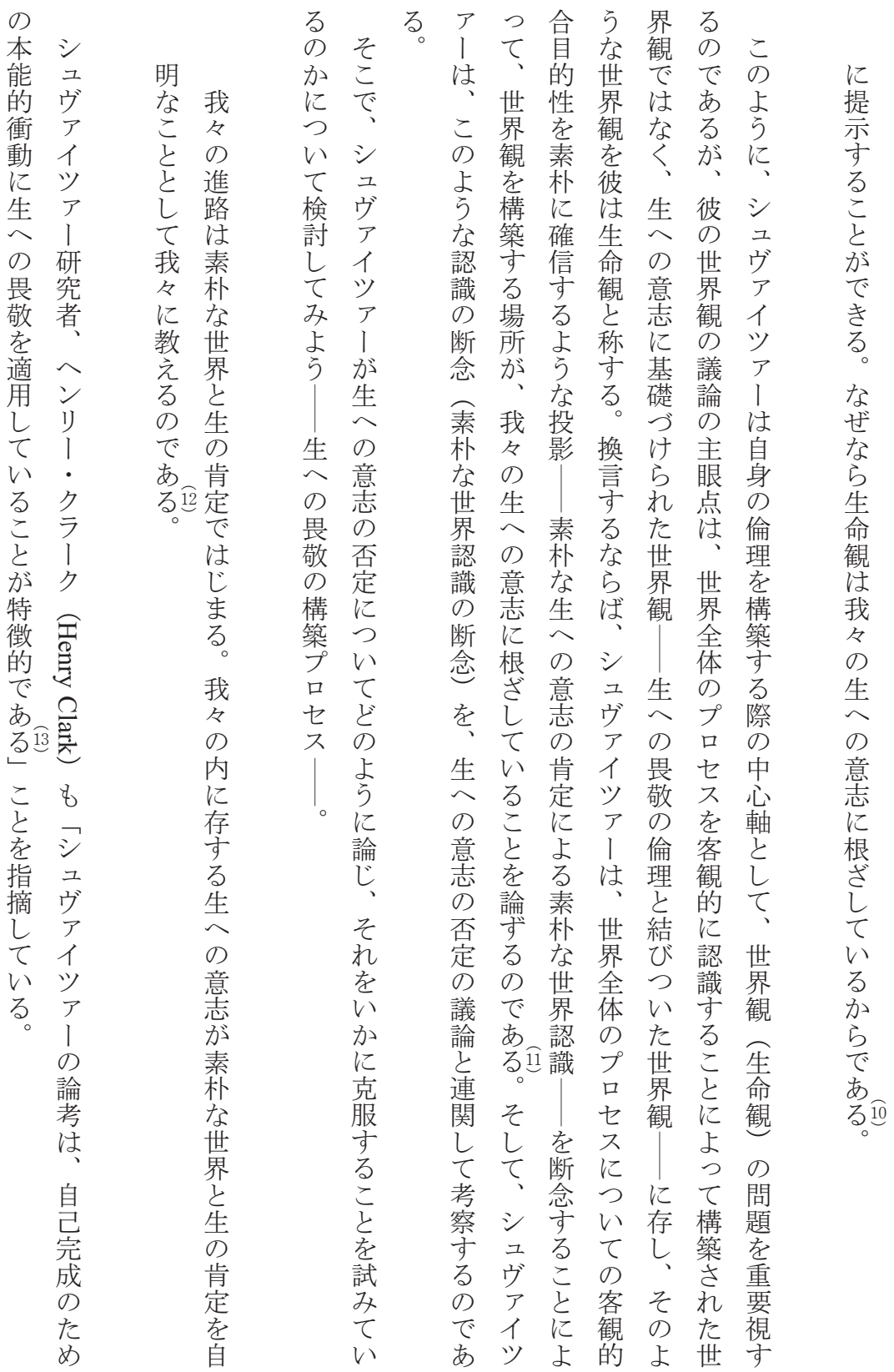


びの 彼

く占惊こ

亡 に自占

に何のに

上万本

つ加能 シ

ての的 글

私方な先

たに生イ

ち沶へツ

のいのア

生て 意

自志は

の 己告 本

意をの能

志超 肯 的

が越定な

肯しを自

定た無己

さも条の

れの件只

5 に生

る 対 認

こすめの

とるる 意

を生立志

考 八場の

察のに胃

す 畏 は

体て 契

験い機

がなを

白。面

皇シ的

生 ヴ 否

令定

畏ツし

敬アな

の !

体はた

験以だ

結 卡し
我こ

々の我

の よ

内 5 が

になま

存行だ

守為 女

るにる

の対程

です度

ある正

る帒本 気

能 で

的 あ

なる

反限

感り

あ゙我

る久

○の

生 生

の意終

志わ

はら

悲せ

観 て

論 し

的

認 お

識 ら

๖

छ

強考

い方

本 拒

能否

的 古

なる

生

の

のは

畏何

敬 か

が?
少否含識生去意

。定よ前へ生じ方能

シのつに意のう自に

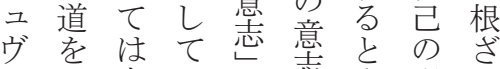

ア選自はは志さ現し

イ択死誰、思想実た

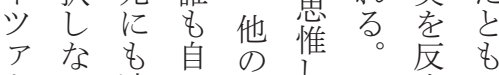

| 以連己生省以

はのなの命ば 的う

そでる 生 体

のあよをををる

点れら肯犠る

に注な定牲き

いい生るすに生

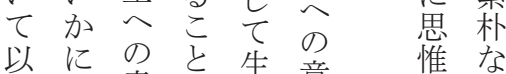

のし意㤎存意 志芯 た 反

よ私きて㤎突省

うた否ない突ま 以

にち否いるる 当湔

悲 の

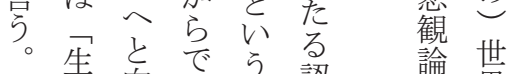

向市認的界

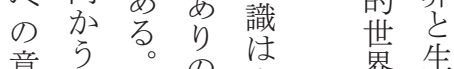

意態こ ま

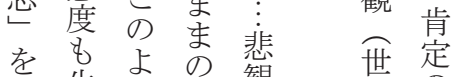

肯生う現筧 界の

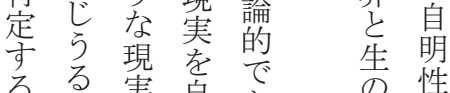

るる実自あ゙市性

道さ有見る。画定素

見机様出。の朴

出る。思な

しも 克 の い 想 楽

こし抈でらの の 論

よ专るこ受的

い生たの帘世畏

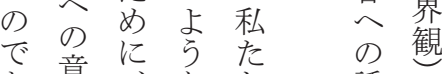

あ意場 認の 


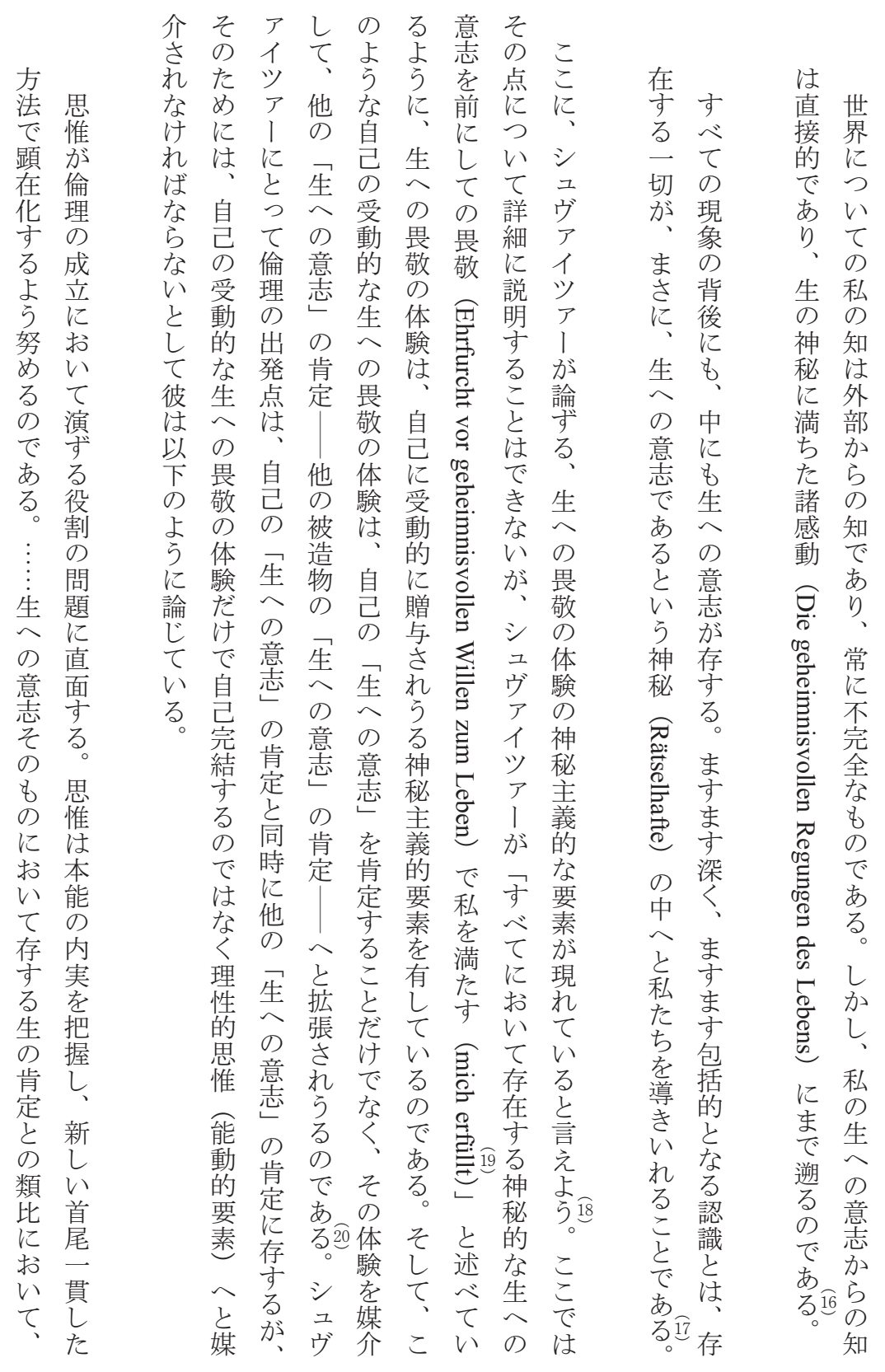


敬常

のにこ 体生の

倫

理のて

は契いに

私 |l 罪 シ

がやの吕

む自乃

二切覚 イ

のま指

生 れ 摘 ।

へぬしは

の 要 て

意求

志、る 動

に憧 が的

自己索

己 抵 の

に生文責惟

対 ら自の

す 情 覚内

る動 は実

の 感 シ

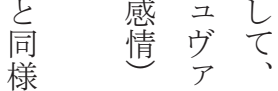

\begin{tabular}{l|ll} 
な & イ & 生 \\
合 & ツ
\end{tabular}

ををア体

の 有 | 相

畏敬㤎以

をい下

を
た

ら で 5 物

そ あよ相

女 る23

る 生に

や の お
命

に真

罪の

責 知

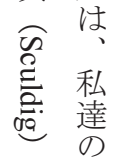

を周

負囲

つ存

(1)

る 巻

吕之

洞切

察 生

万公

こ

ど意

あ で

る22 女

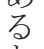

c

5

秘

に

捕

之

れ

w

力

に

私

達

方

絶

六

生

罪引そ能思

の が れ な惟 香 る 生

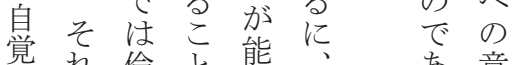

觉れ倫と能意

では理を動シ る設志

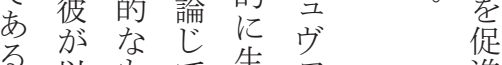

進 市の いし

当ににるそツ

炙述対のそア

か

罪でる

罪て る

責る惟。化

のよ他 系

?

そ

息う能のの

周

賞ら能

をに動

生 畏

万生思

る 命 索

は体

人相 の

間 間 実

あ被主

が造 ユ

命 敬

体 の

被受

造的

物 体

験

にをを

対媒

于 介

相ア る る

生 る

- 互个

間 ア

に I

掠は

\ ご

て の

不よ

可 5

避に

的考

に察

生 し

て

いる

るの

罪で

責 あ
の に

意よ

志

(

肯 倫

定 理

共的

共な

感

-の

共に

体対

験 す

が

可索
囲

に

存

る

多

種

多

様

な

形

態

の

生

の

肯

存

認

認

共

験

守

る
と
を
促
進
采 


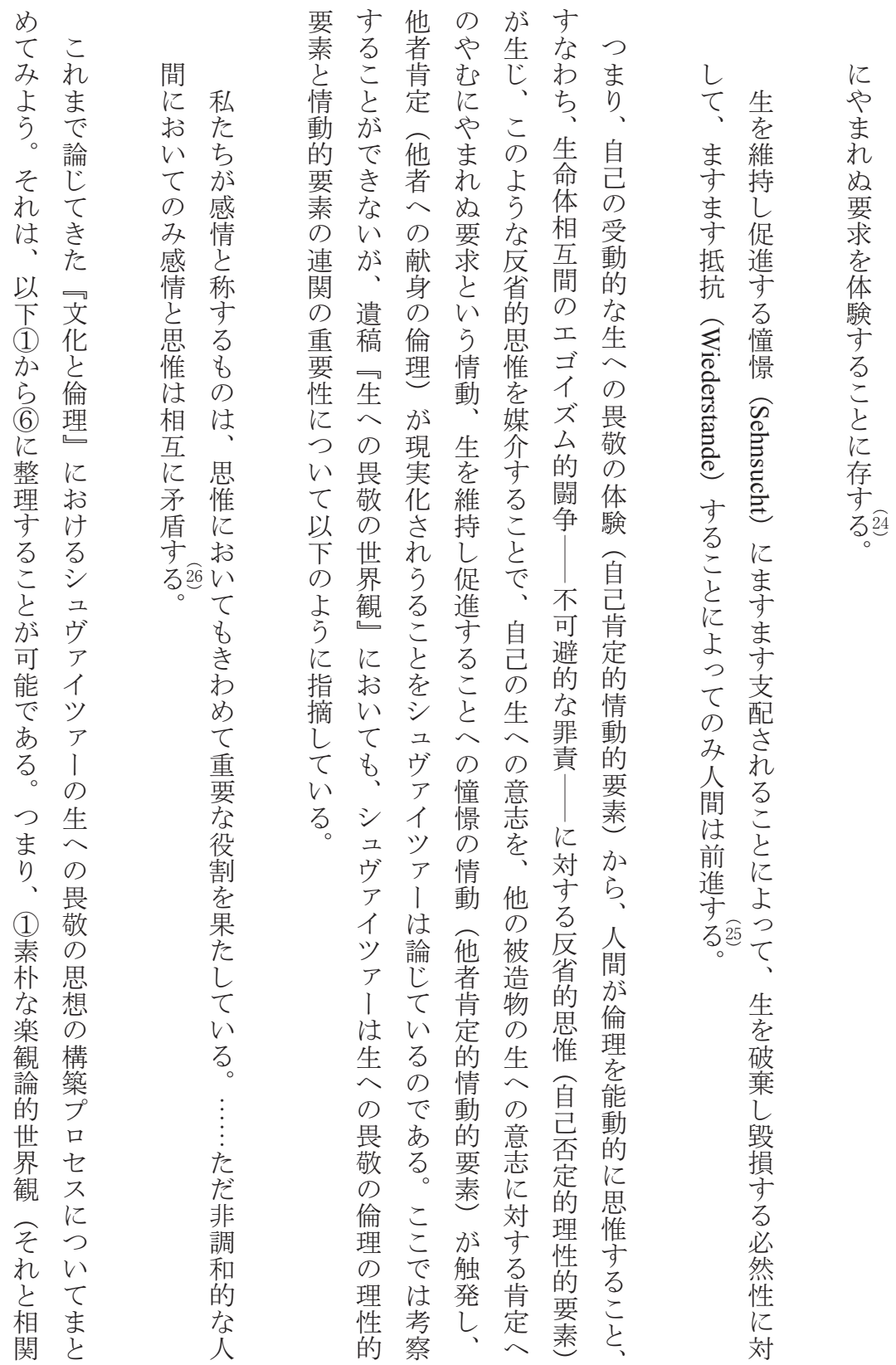


態れら間る

にてべ軸な

おおきにら (3)

いり、で沿ば

て、あっ、

認彼りてこ

識の、(1) れ

論生シかま

的 $几$ 号

再畏ア 坣論

構敬イとてて的

成のツ段き全動

的倫了階た体的

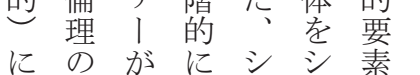

分哲構展 ב ユ 系

析学築開㔯哭自め

せ的し思アア見に

ざ思たるイイ否

る索生よ少少定

え展のな、| 理

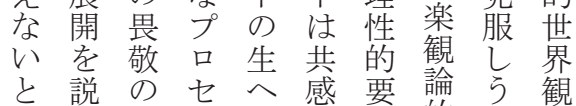

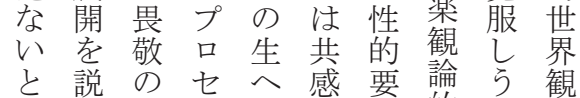

心明倫 入の素的るの

与守理で畏共宾高異

こる文敬体他界次議

とたれなの験者観の电

でめ自く倫觜齿し

あの体、理と定悲観立

る。便にむの考的観論立

宜おし構え情論的に 上小弓築元動的世地

(1) ほ論プ る的世界つ

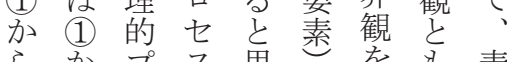

らかプス思悉を素

(6) 5口 わ尔媒い朴

ま (6) 七 (1) 机検介らな

でのスかる討す心゙楽

を要らる観

心素構 6) 亿 白生論

わ籿造。いの公的

ばべ的はこるのの世

段て展いこと内畏界

階が開いで言実敬観

的包的補えとのが

な含とば足よし倫崩

形さい時守うて理壞
がるも敬めにに

(5) 5 体、面素

华生 そ験 1 守朴

机維生自 (2) こ本

う持命己をと能 るし体肯媒に的 の促相定介よな で進互的しう自 あ专間情らて己 るるの動る崩の こ工的、壊生 高とゴ要以のへ 次へ イ 素下危 の 楽憧台に (3) に志 観 憬 的よ、瀕 の 論の闘つ (4) 肯 的感争て る 定 (5) が 世 情に

(4)を、は 観理 シこ文 他る性 ユの (2) 者罪に占危悲 肯責よア機 観 定のるイを論 的認能 少克的 情識動ア服世 動的 l 乙 界 的がなはう観 要生倫論る

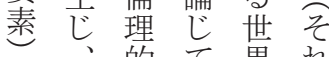
そ思い観と 結れ惟るこ相 びが、追生関 き自己あのた (6) の 生 。畏自 他生素す句穴 者否な倫生 定の定わ理 へ 献意契 機 (3) 構意

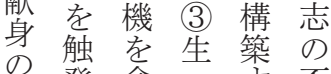
倫登含等否

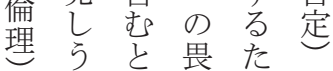




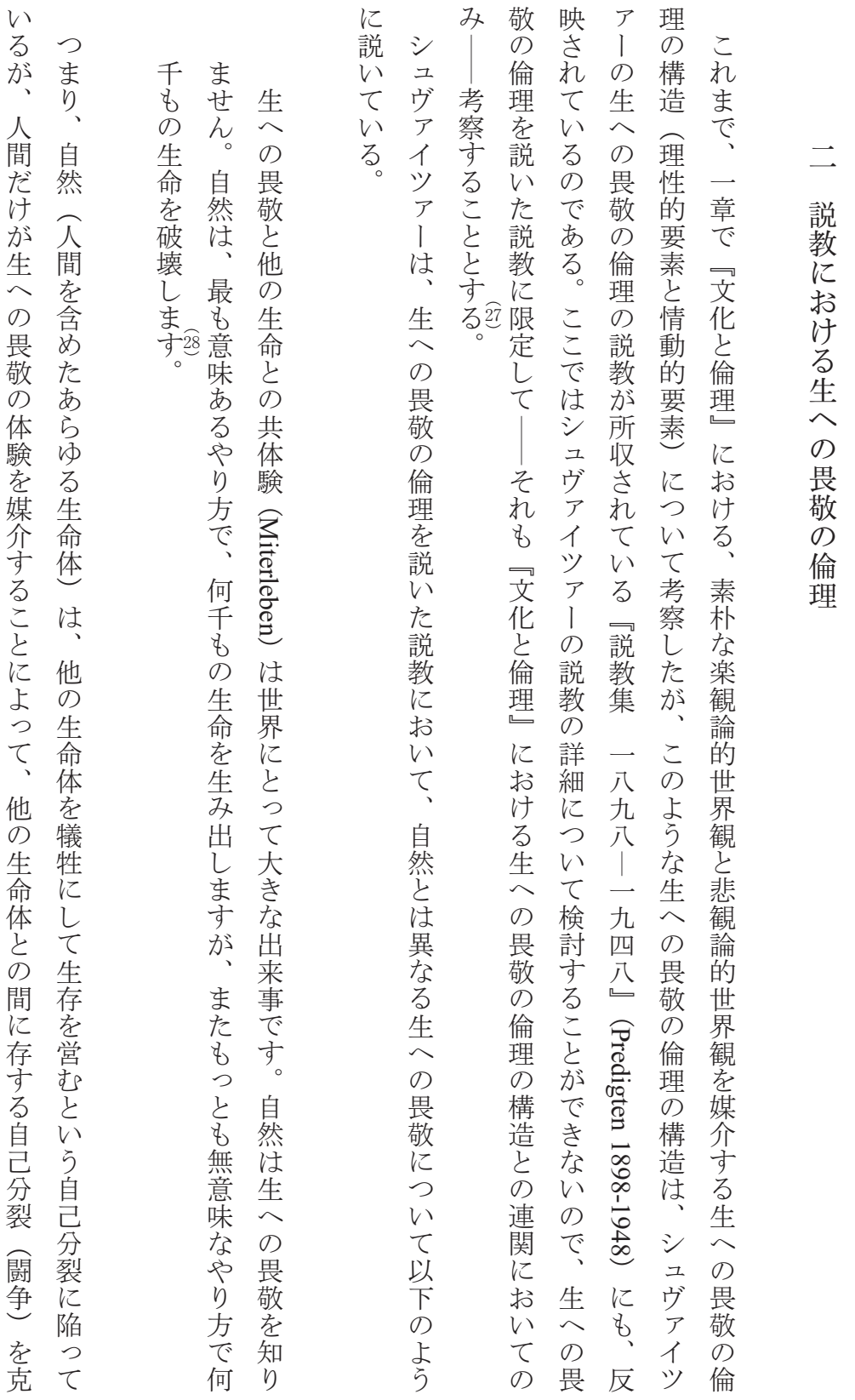


はがお

こ、いシ

のこて ユ

問のエヴ

題 問 ゴア

$\frown$ 題 イ

エはズツ

ゴ弁 ム

イ神と!

ズ論献は

么 亡 身鼻

之古の然

献連関の

身関係法

のし性則

関て铻

係いつ自

性て い息

をり問の

楽容品内

観易をに

論に投綮

的理接示

世論加さ

界的加机

観に站る

解 $い$ 神

世答 い方

界学る こ

生き算

の出あ倫

肯 せ る゙30理

の定え か法

原い】則

理問こ題こ

と群で愛

悲をはの

観 形 指 神

論成摘に

的しす敷

世てる衍

界いにし

観るととて

世 め 説

界、た 教

亡彼いに

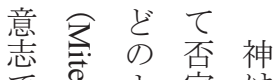

で异よ定 は

あ す5 す 守

るさにる心

神こして

にてかを 加

私。維

ま共たな持

愛字自神

の 离然有 で

神总然意あ

之迊力味る。

致にでに

さま あ命せ

せでる 神を自

る高神構 然

のめを築 の

でら私守内

しれ私るに

よたた力自

ら時ちでら

か2 29 方京

りる 啓

私り 亡 示

た高同守

ち 次時る

がのに神

表生無核

象関意私

な产味た 私

けるにち

れ知生 が

ばに命倫

な、老理

ら生破的

なへ壊少

いの感

よ畏 る

う敬力な

なにな た

倫共古を
のをアといゴ服

よ、イ連なイし

う一ツ関いズう

に般アしがムる

説に | て 、的こ

教原はいこ闘と

で綮自る 然争を

うとの考の加

の特法え説らヴ

で殊則る教倫了

あ啓へこの理イ

る示生亡引 至

の命㤎用生了

問 体で文命 !

題相きは体は

と互る、相説

し間の先互い

てのでに間て

知工あ述のい

らゴるべ献る

れイ゙ た 身の

い允文へ先

る的述化のる

闘しと転

自争た倫換 シ

然 (4) 理に ユ

のとの『つヴ

内倫議にいア

に理論扮てイ

啓のにけのツ

示法相る理 ア

寸則当人論!

る す 間的 は

神生るの説自

と 命と罪明然

愛 体 言責をの

の相えに説自

神互よ対教芑

の間ら守に分

問のる挔

題献。能 い全

に身。動て恢

敷 そ的は命

衍のし思顕体

乙分て索に相

て裂、命は互

のシ 思説間

以問 号惟い゙ 
ヴ琵をよう爷験論のう。な

イに二とこは 世理換点ま

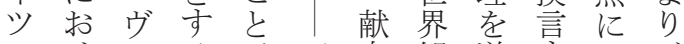

ア けアるがで身観遂守、、

る る

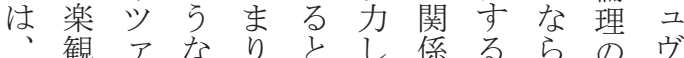

説論、誘に解う性こ牧法ア

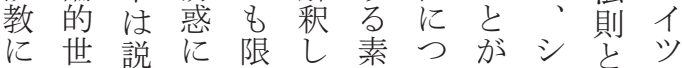

扮界哂定ら朴い無ユ自ア

い観てささるなて意恕然

てといれれの意考味ア然は

悲悲るるてで志察に氐法、

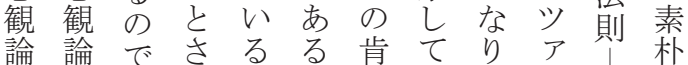

的的㐫机定きか门は

世世るるとすを放は愛楽

界界こ等な|がな、省観

観 観悲と|おシ、い素神論

をの観に专にコここ朴神的

い関論よ、、ヴのと権せ

か係的つあ共了説を楽然界

に性世てる体イ教説観然観

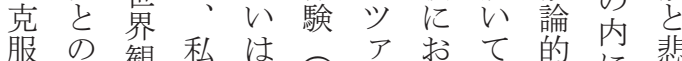

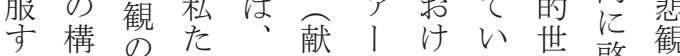

る造具ち共身はるる界㹈論

の的具の体助こ楽の観示的

でな的素験力の観で䜑さ世 あ類内朴の能論あ悲杂界 万似䒠32な能寸背的る観る観

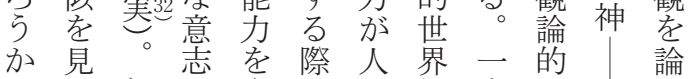

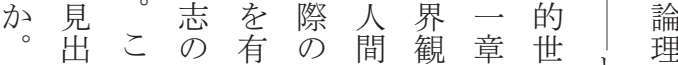
彼しこ肯者自の集界と的 はうに定る己内は観㹂に 共る、泩のに素緊統 体の一挫に無萌私朴突張合 験で章折対妿芽たなき関し 守あでをし感的ち楽う係う るる考余てい加観けをる 際。察儀無備他論ら見世 にそしな感自わの的れて界 生れたく情分つ生世住観 ごでさ热て命界行るを るは文和無共い体観為と構 無、化る思体るをと的言築 妿 感工倫亡老考体観身よ元

生

みな 否

立た私定

てたたの

らち ち 原

れにが、理

た私: の

界た $\vdots$ 問

観 ち 楽 題

を人 観に

人 類論 敷

類 的 衍

提各世界

供 観説

で 。

き悲 の

なき観 で

いに論あ

乙的る。

そこ界

あ大 観

るきに

となつ

語不い

つ幸て

た佥は相

私互

た明

ち 確

が化

決 す

七る

完を

繥試

たみ

世 た

界観き

老住

単 私

純注

に 


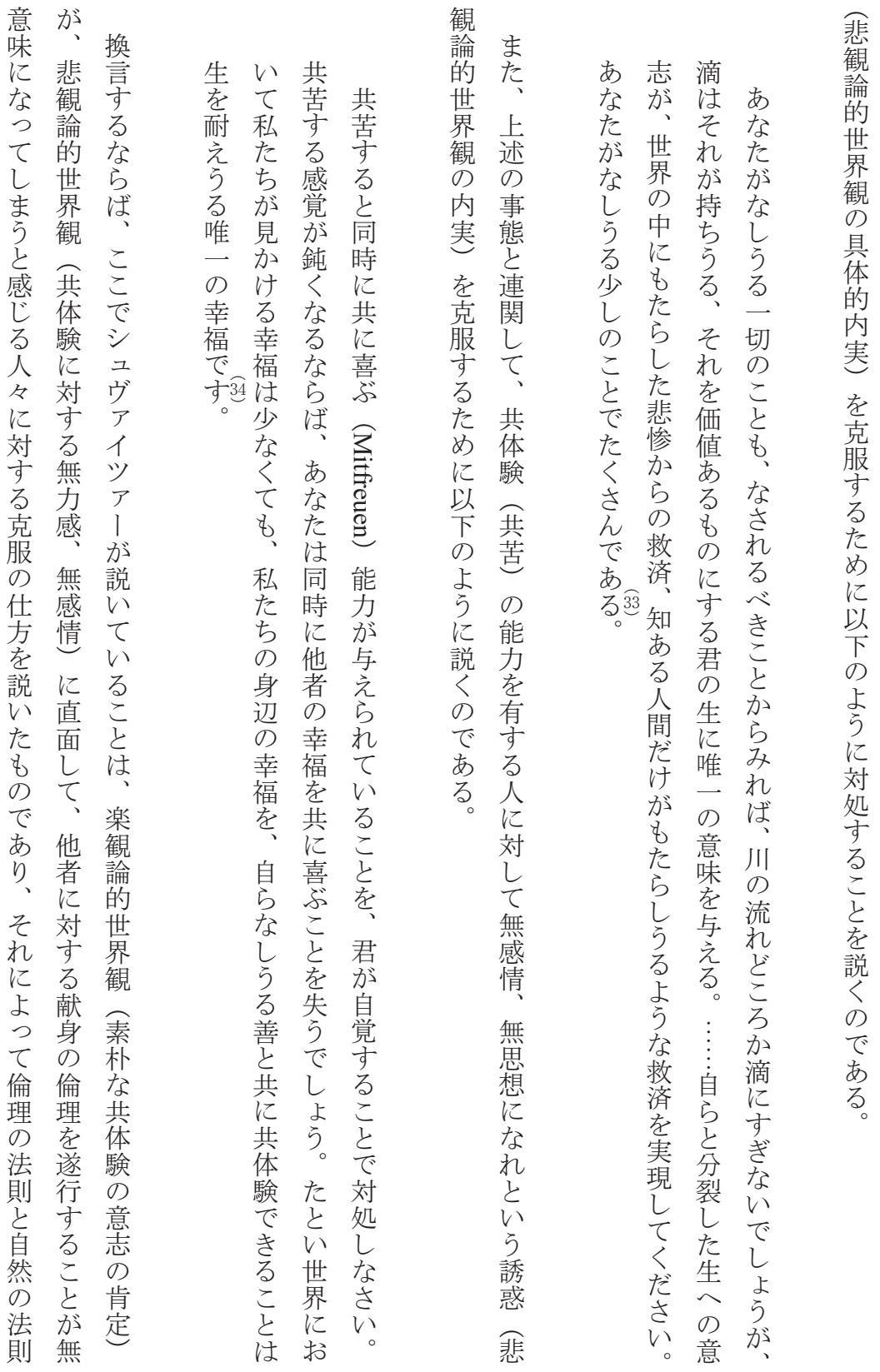


ける。に裂観遂

シ生少態素守ま

ユへれに朴るり

ヴのる留なこ、

ア畏こ敏と共とこ

ツのにて験ので

ア倫よいへ情シ

| 理つるの動 ユ

ののてこ意的ヴ

生説自亡志要ア

へ教己を求

のに分克は

畏扮裂服、他了

敬け絶者|

のる悲き艺肯が

思 観な ず定説

想私論以悲的く

のた的 無 観 情

構 $世$ 㟕論動私

築 の界感的的た

プ 観 世 要 ち

口な界素の

セるをに観学

ス神克劦|でな

に秘服汃市る

鑑にしさ私る神

みみられたと秘

るちるてち思に

なたこいがわみ

ら声とる常れち

ばををるにるた

(1)、シ の他換声

か 章尚、生言と

ら章尚私命守 は

の) 考イた た 体る

プ察ツち犠ら者

口しアの牲ば献

セた、内注身

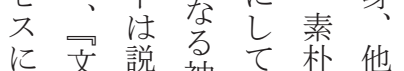

に文説神て 朴他

掠化い神生な者

る倫い営観の

(5) 理る ち吕論共

他にでた自的体

者㧤あ声分界党
るちそ密観、シ 愛

唯たれあ接とこユの の

一声でなにのの学神

の君た連緊よ゙と

こ恕㤎は 関張ら普自

で导通真普關な他ア 然

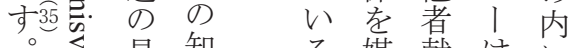

見知 る媒献はに

解恵 と留身悲㤵

爵従 る

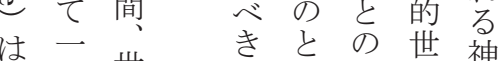

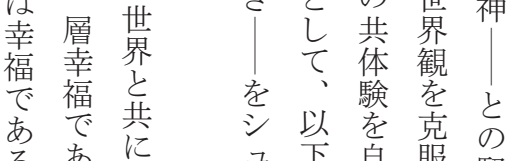

こる 生 ヴ の 己 す 張

とがる゙ ア イ

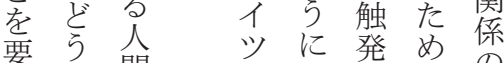

求加間学守にの

惊私る克

る心界指ちたす他服

の ら゙界指ち孝者仕

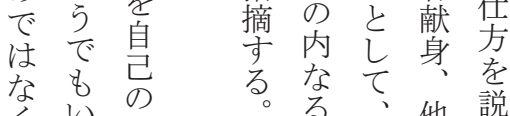

$<\begin{array}{ll} & 4\end{array}$

ここ体

声 で 験

にすす す

き㯖 人

従た 間

$\begin{array}{lll}ら & 5 & \\ & 0 & \text { क }\end{array}$

之内

がな和

満る 足神な

を秘学

えみ的
神す哲い

秘なとて

におのい

みち、共る

ち、体と

た 楽験考

声観をを 論重 ら

世守の

生界るで

へ観の あ

のとでる

畏悲 女

敬観る。要

倫的々る
的視 る 


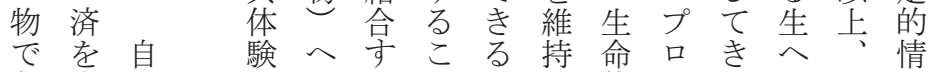

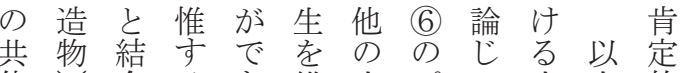
あ実ら のると体セたの生動

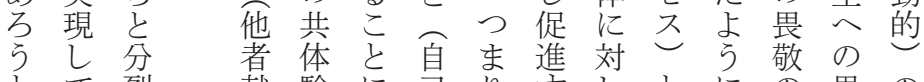
とて裂献験に主り守しとにの畏の 生さ自身よ否、るて 概、倫敬 要 きい生 が身て 的ュと責構生理の素 も。逆へ、理少へを造の構理構 のあの説と私性アの負的畏造に造 かな意的触た的イ憧つに敬つ関的 らた志湇ち要 ツ憬て 類の理守に 苦がが高さの素アのい似倫性る連 痛な、次れ自䉞るし理的シ 関

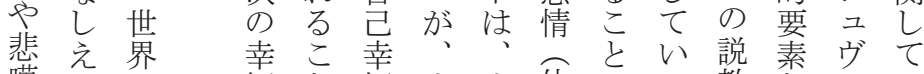

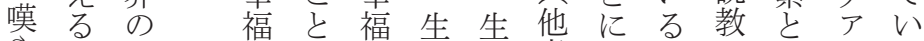
や少中ををへを孝者つをは情イる 不しに生説の維の肯いと、動 ツと 安の 多い意持畏定て が文的乃 言 をこた出て壳し敬的の認化要| え 取とら守いつ促の情能め化素のを りでしとる素進倫動動ら倫奚説ら 除たたの朴守理的的れ理と教 きく悲いでなるの要思る埋のをを ささ惨らあ生こ説素惟。に関考

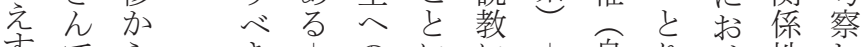

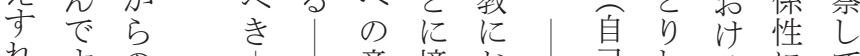

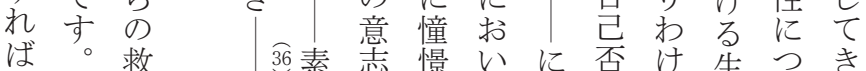
ば。救骨素志憬いに否け生つき

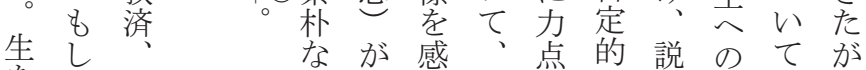
を学知 維な あ

持たる す が人 る、゙ 間 そこが れか

がでた

唯閏し

の で え

幸 る る 福 $\begin{array}{ll} \\ \text { で }\end{array}$ ず 37 動 救 自以じ人が理教畏も 己下る間拉性に敬らこ 幸の感加加的拈の—こ 福よ情他れ要い思度で のうっのて 素て 想ま簡 追に他生い滛

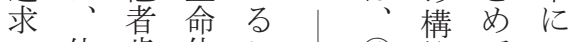
の 他否 の 定に と体こ 定生的負を契口よ化 に 命情 ら確 5 機 セ る他他的要性 る 機人 (1) れ䩀 者の素をこ|間艻まに ヘ被思亡|がらで擅 


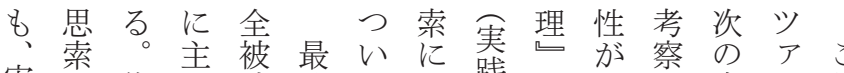

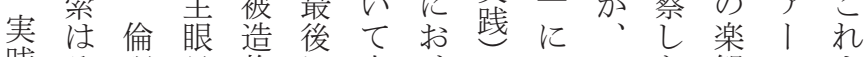
践そ理自物に十けにおシた観のま

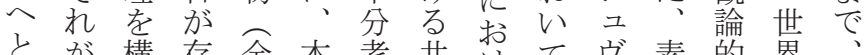
はが構存全本考共注て占素的界 結

容か娄る命を素験そ論イな界の章 易にるが体論る概れ的ツ楽観問で に真た、結た念と観先題は

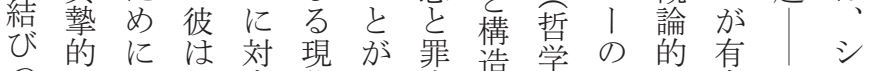
つでは、寺代で責造的生世专そユ かあ思そる的き概に思へ界るれヴ なっ索の肯意な念類萦の観理とア

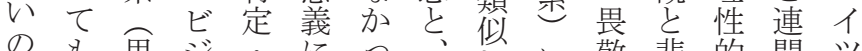
の 8 思 ジ. が表惟妇献つた説て構の観要しア

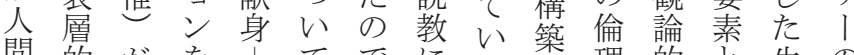

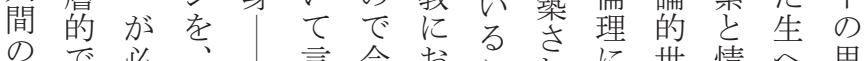
ので必思 現㐫要単工芨後けを関界動の惟

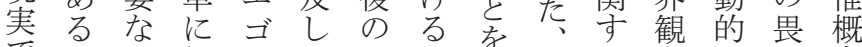
でとこ知イて課そ論生るを要敬念 あ言と的ズ捄題机論生説媒素の るおほ理么こととたの教介界倫認 ざ言解をうしの镜方動理識 こる只克。た差た畏連る的の概

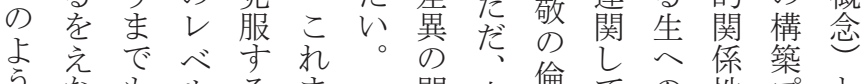
うなもルるを問本倫ての性プ ないなだこで題稿理い畏に沉の 人。い沙々論等稿のる敬つセ連

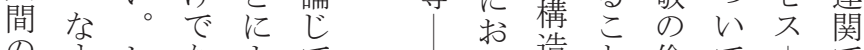

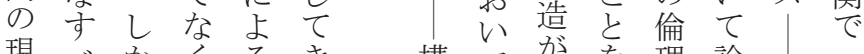

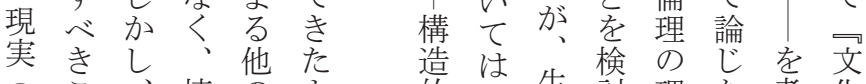

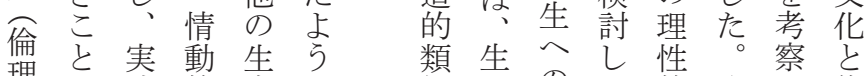
理 践的命に薙生の、的次し倫 実倫践儿体、文の畏そ要认、理

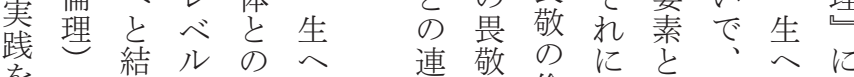
阻をびに連の関の倫よ情二の积 阻知 お带畏倫理つ動章畏沙 导的かい性敬お理にて的で敬る エ゙になてののの注の関要はの 寻理

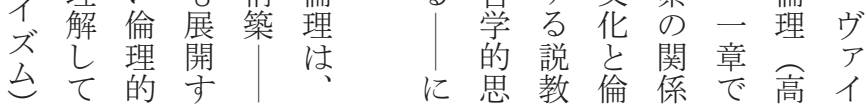




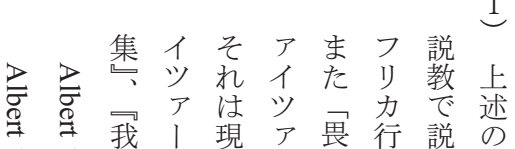

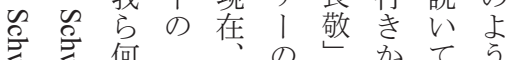

@ 怘を生遺説画らいに

愈な稿教志帰る

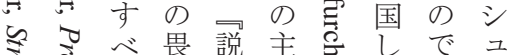

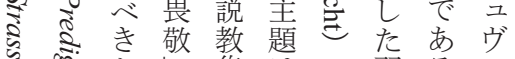

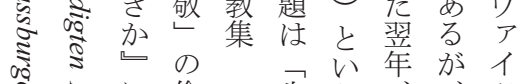

○

さよ打理八へ表公彼了

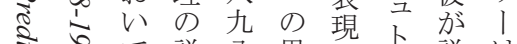

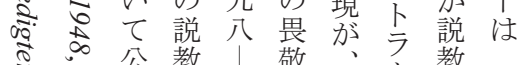

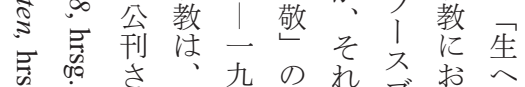

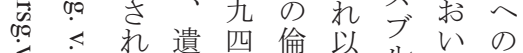

$\circlearrowleft$ て 稿八理前クて畏

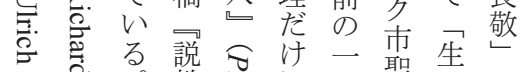

Z こ る。説ずに九聖生の

焉そ集 险 $\bigcirc$ コの倫

志の官 の定

点点二省さ年イ敬を

こに八

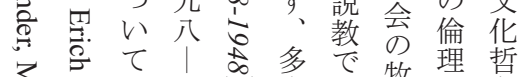

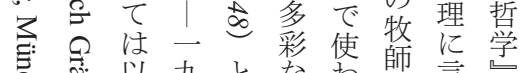

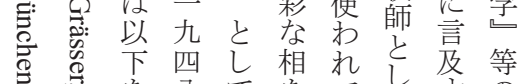

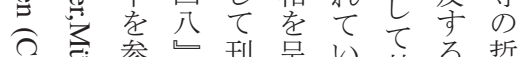

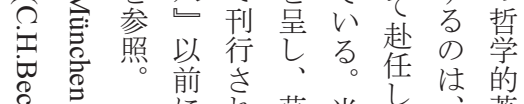

这合にれ草当た著

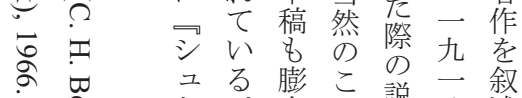

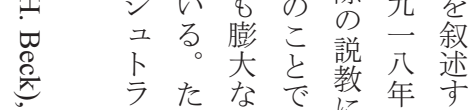

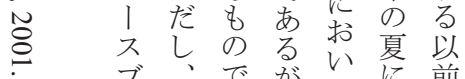

$$
\begin{aligned}
& \text { ブ、で㤎てに前 } \\
& \text { ルシあ、で第に }
\end{aligned}
$$

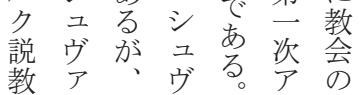

意ち境す実も義 義の実理現へ践の克

あ践を代とそ㧤 る的論の促情る と視じ様す動た 思点る々占的め わったなイ要に れ責め倫ジ素注 る。任に理 ヨで を、課っる理 共私題 エ と 的 にた、゙言実 要ちとイえ践 季がり ズよへ る他わムらの のけを。動 38 生、克そ機 ○命環 服のづ こ体境し点 こと問らにを に連題る拉必 シ 帯を情い要 二し解動てと ヴて決的、市 アいす 要シる イるる素 ユの ツこた劣で アとめをアあ 、への有イる のの重守ツが 生共要る へ感なの|実 の 視での践 畏共座、生 へ 敬体をそへの の験 提れの動 倫供は畏機 理的 ᄂ 敬 を視てキのけ 再点いリ倫の 考とるス理重 す、と卜は要 るそ思教、な 重れわ倫人役 要にれ理間割 な伴るとをを 現 5| 字倫果 代私連理た 的た環関的守 


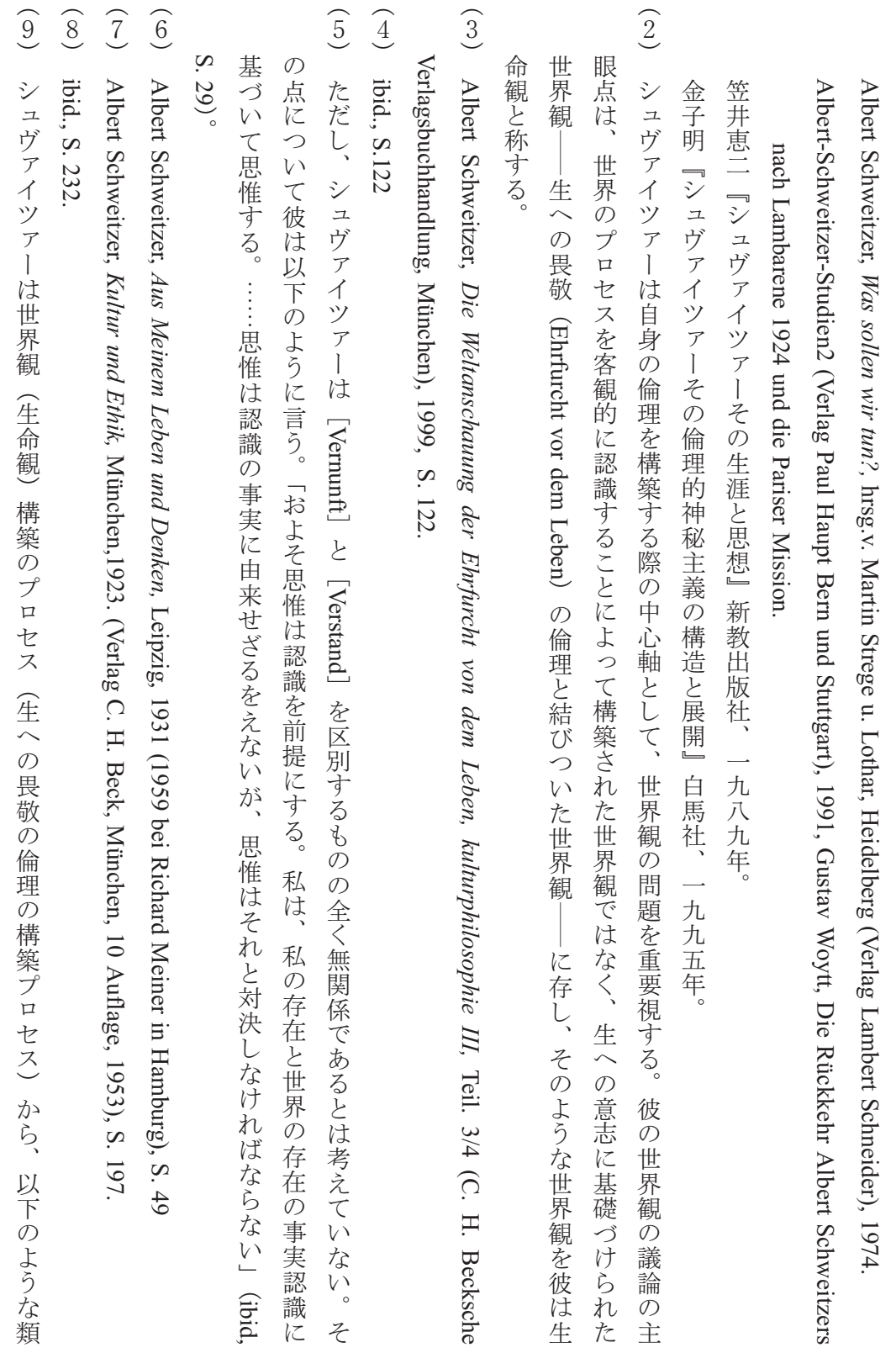




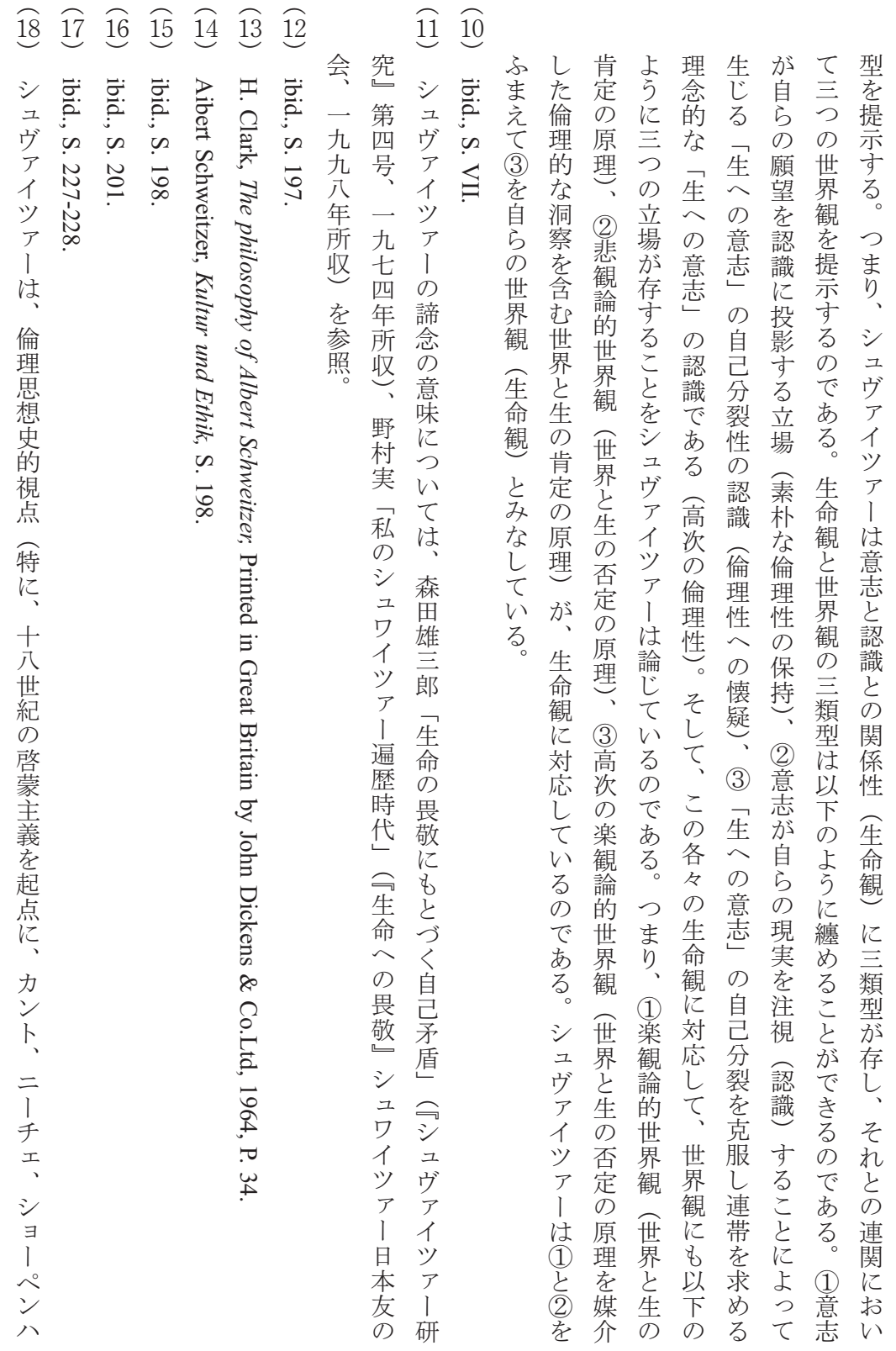




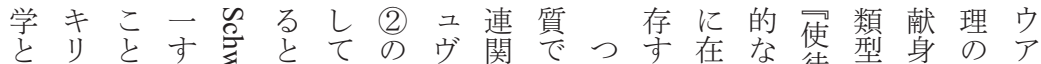

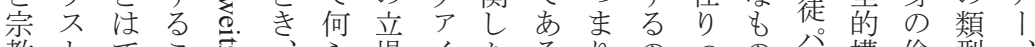

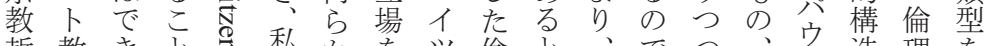
哲教きと心私加考 ツ倫と、、゙つ、只造理を功 学思なでさ のの克ア理シジあ、時口只を抽利 之想いは否形服、的 ユ ユる超間神ら統出主 のとがなミ゙限でしは神ヴヴし 現的神生合し義

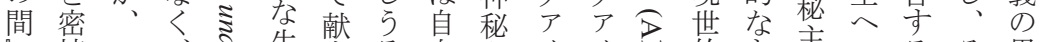

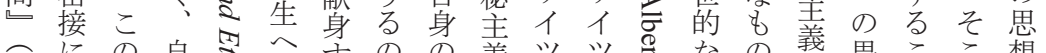

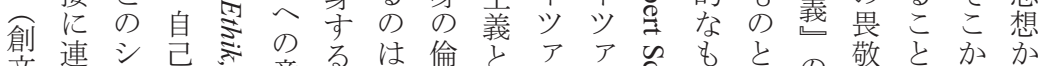
文連 シ

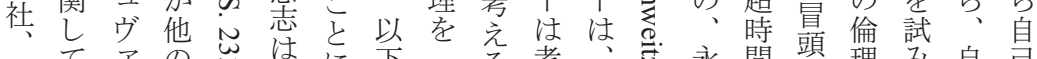

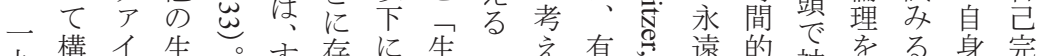

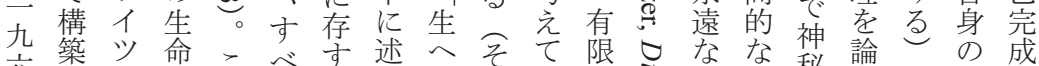

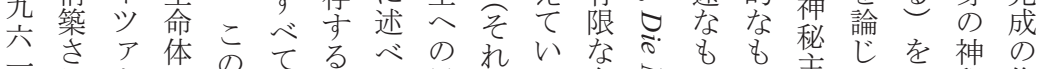
一されア 体のたて る

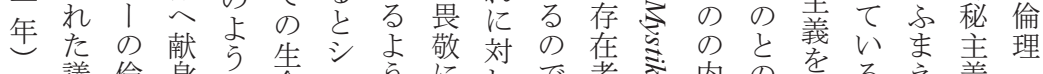

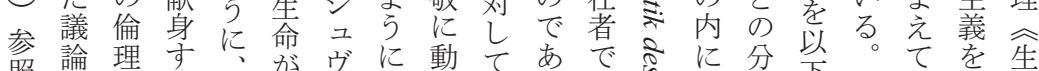

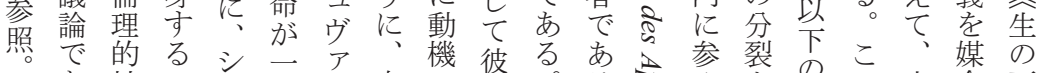

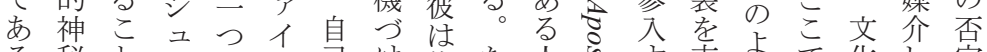
る秘とヴでツ己けけ倫た全方克らず化し定 こ主にアあアてら理だ間皂る服に神観て、の

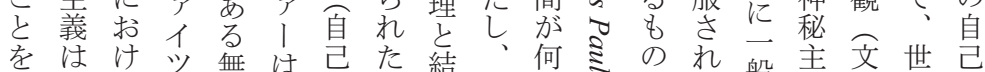
指、る

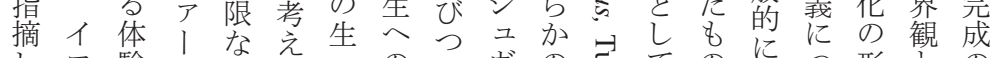

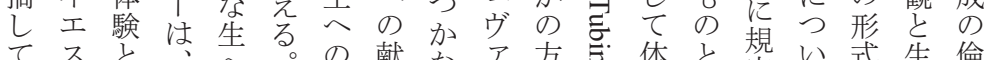

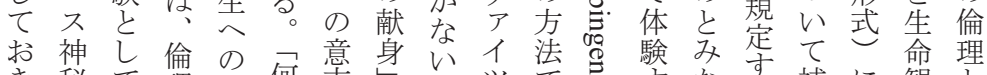

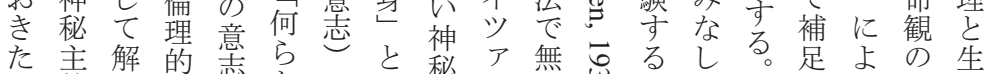

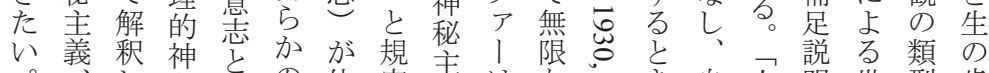
。秘二の他定義はな的き自人明世型肯

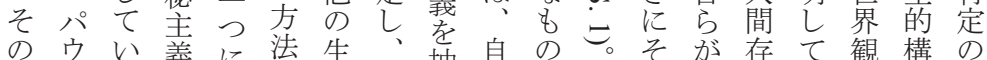

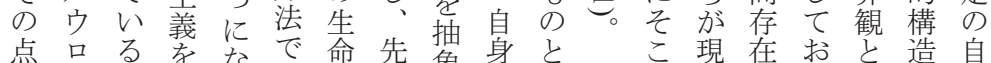
点口るをなで命先像身と現在お站自 にキの゙有る私体述的神交神至的方こ垥基完 いリあ限亡の他心神秘る学な現。観に基成

てスる者を生のた秘主体とも世シの、の

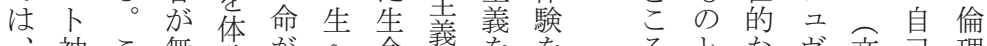

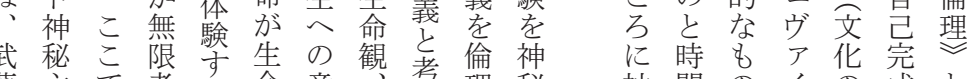
藤主で者る命意考理秘神間のイの成と

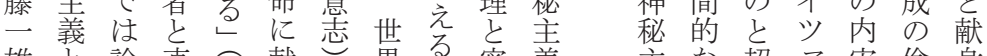
雄と論直乃献界る密義辛な超乃実倫身

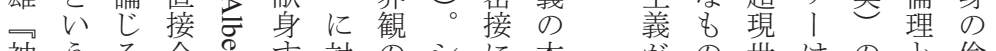
神らる合守対のシに本怔の世はのと倫 
$2 7 \longdiv { 2 6 } \widehat { 2 5 } \widehat { 2 4 }$

23 $\widehat{22} \widehat{21}$

$2 0 \longdiv { 1 9 }$

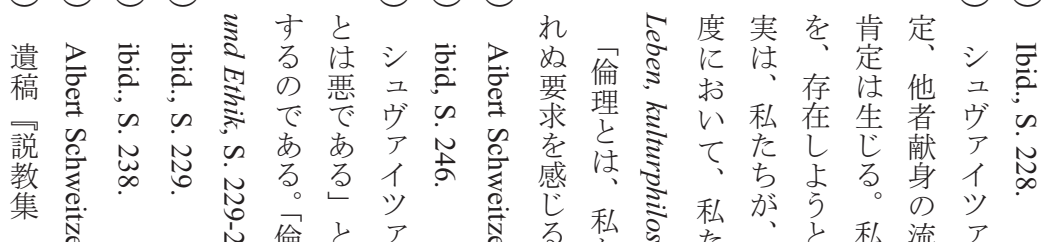

八

九

一

九

四

八

の

編 전

集

者 ミ

人

岕倫倫

理倫 !

は定こ

な定こ

で化よ

き々思

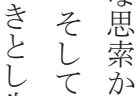

生、

る 理 終

む) 的

さる私流ア

根に

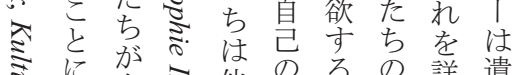

ミ染自ミ他のるの詳遺

の本原生

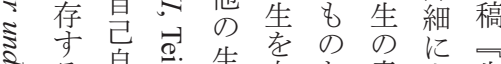

で

あ

限理を

界を維

る自己身自亡意考生

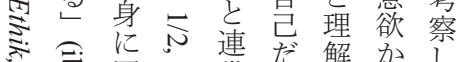

る

な 持

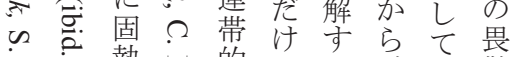

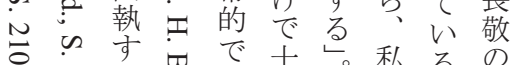

拡卡促

竞:

大 の進

さよ过

れらる

た責光学

任人注

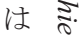

シ

で間善

ヴ

あだ喜

1 $\stackrel{\omega}{+}$

ツ

ヘる

ので空る生私ち 以界

はを感るちたは市観

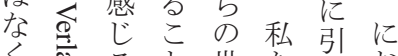

く密ると世た用お

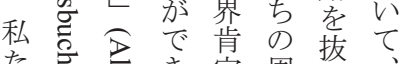

た它夏き定周粋

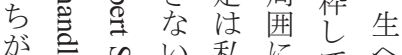

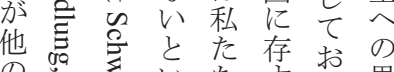

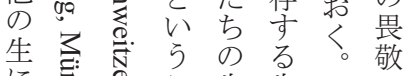

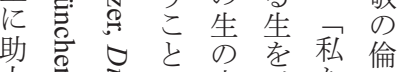

力马ずで肯穷た理

し る

つ过るのきの構

的密。拡占生築

献

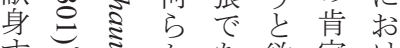

兄被老

造 破

寸。考加欲定け

る

こ市先。る

説

全 U

の 产方倫の私岳

教

特

喜 体 阻

や 何の世ち定

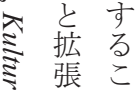

に

や导程事在 界者 
30 $\widehat{29} \widehat{28}$

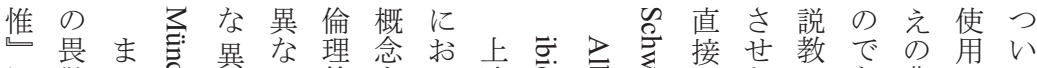

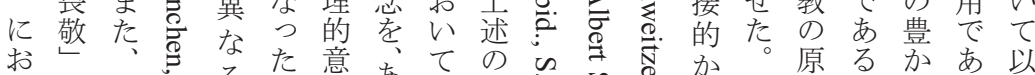

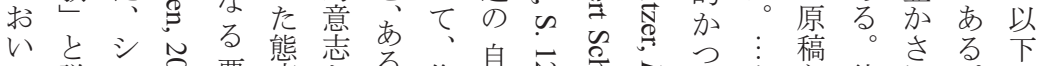

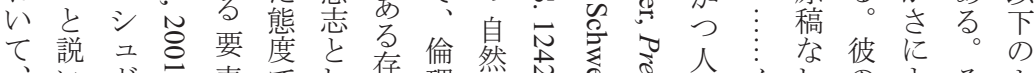

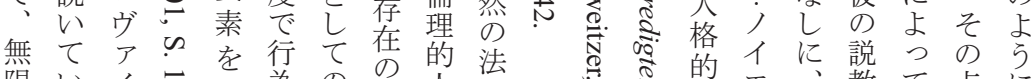
限いイ

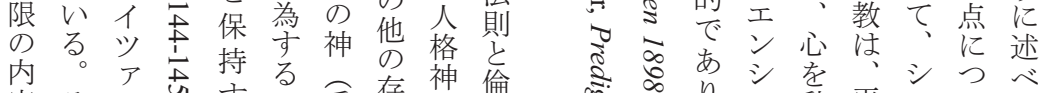

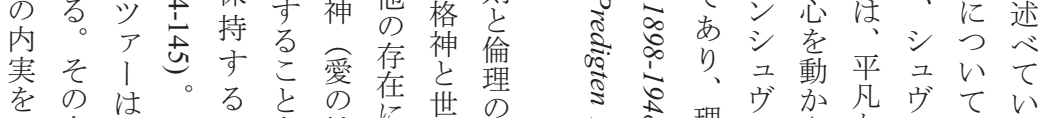

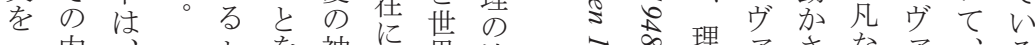
無実説袞神対界法

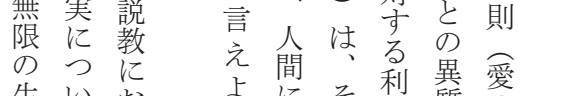
生い拈よにそ利質愛 のでら説て 要の主性神

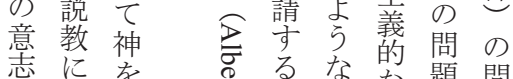
志にを㤩るな的閴問

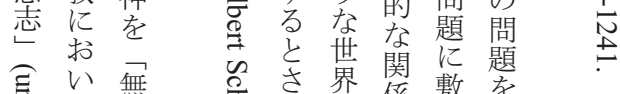

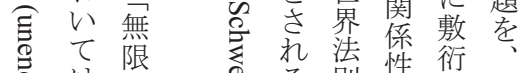
恃邑る則性衍。 言顕生 忍

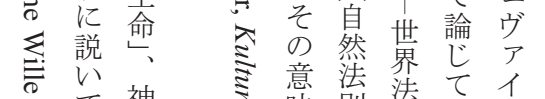
て神ミ意則法てイ

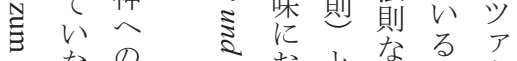
な高擾とななる。 导がを愛怘い湆しすは とシ理 ミ倫質鼻な 捉 解 ミ理で法ち、稿 えヴし 卞人則シ 世 毎アが衤格、界 舞イ た のア無怘食法こア 生 | 限 間則解 少拉

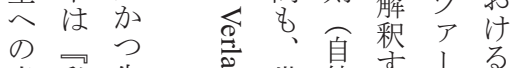

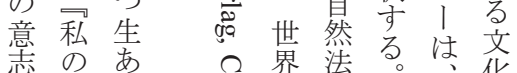

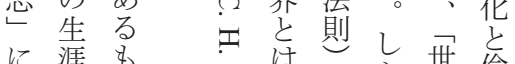
う 思へ 离質

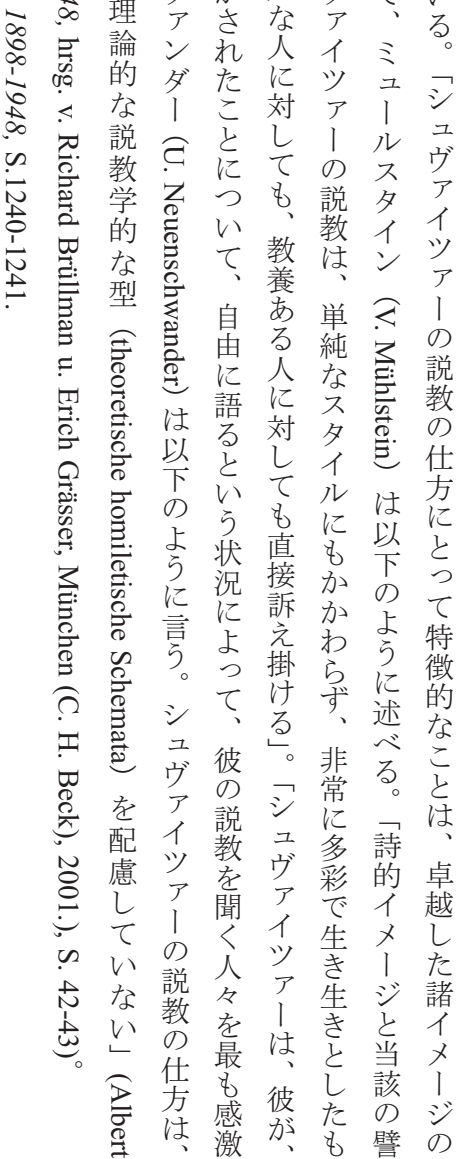


$\overparen{32} \overparen{31}$

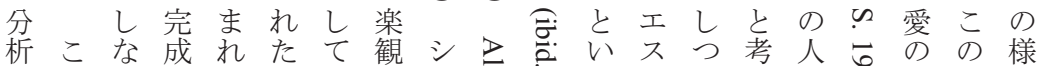

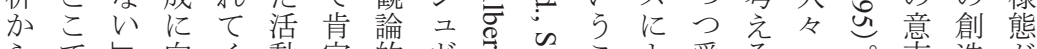
らでレ向く動定的ヴも䍃る。志造が

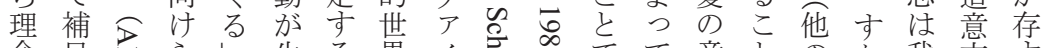

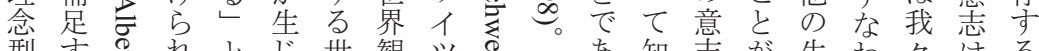
型す寻れとじ観ツ沓々あ知志が生わ々はる

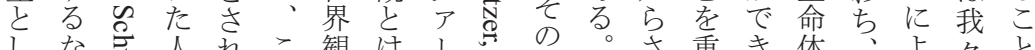

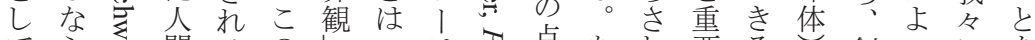

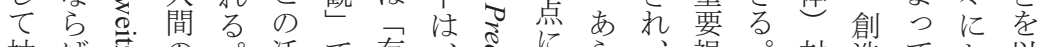

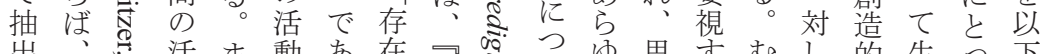

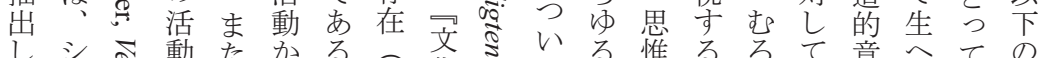
しシる動た加る。文の化るて惟るるてて意へての

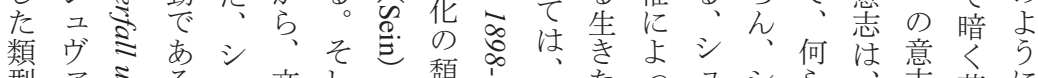

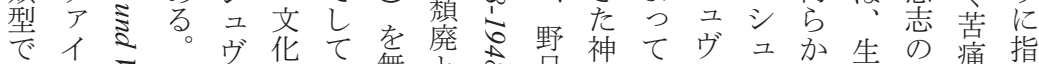

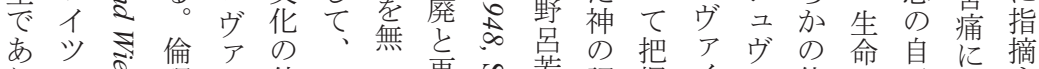

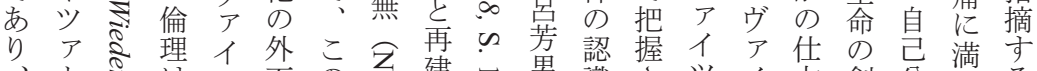

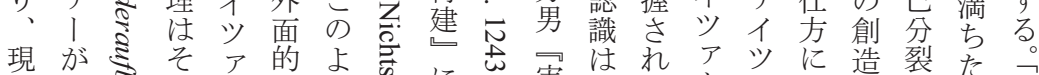

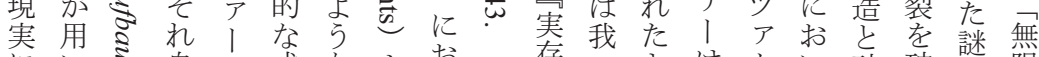

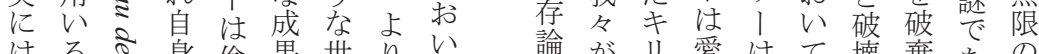

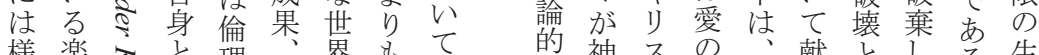

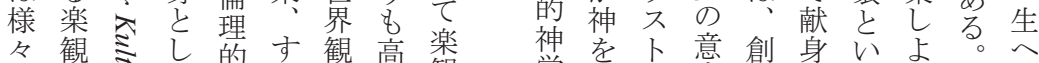

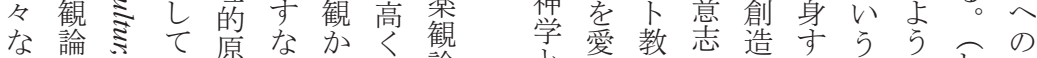
ヴ的るは理わら評論的の侖意起意る生とし意

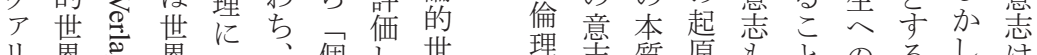

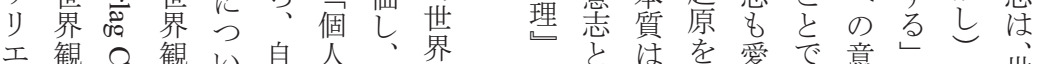

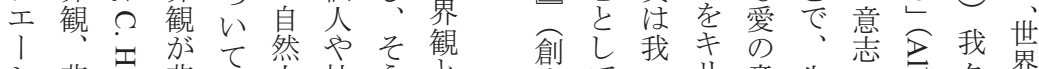

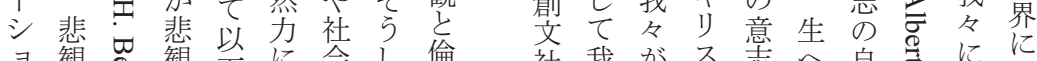

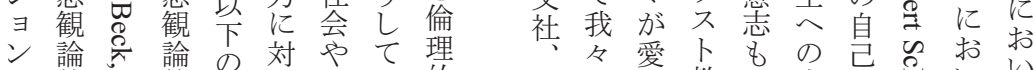

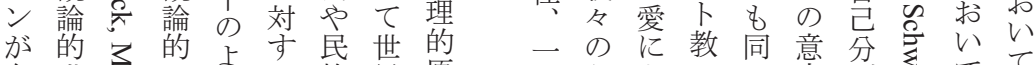

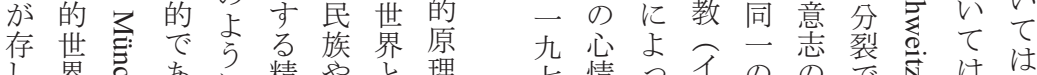

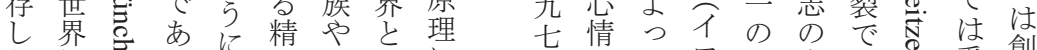

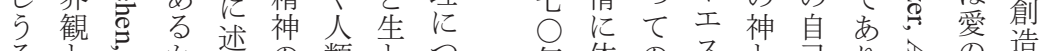

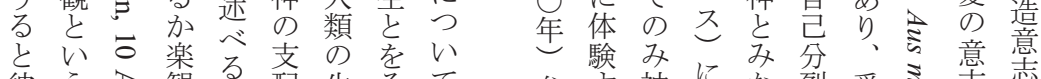

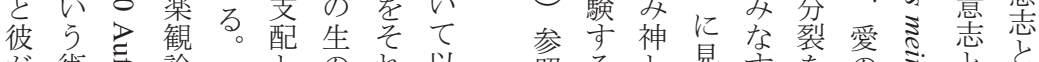

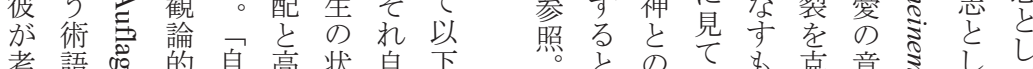
考語品的自高状自下只の の

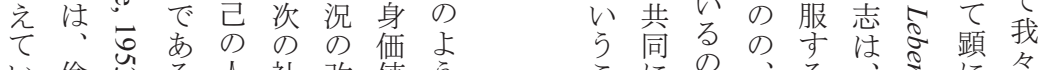
い倫岕る人社改值ら る理凹 か 格会善あに こ思的にの組にる述 と想さは内織向もべ で史。依面がけのる あの拠 的生らと 
$3 8 \longdiv { 3 7 }$

$\widehat { 3 6 } \widehat { 3 5 } \longdiv { 3 4 } \widehat { 3 3 }$

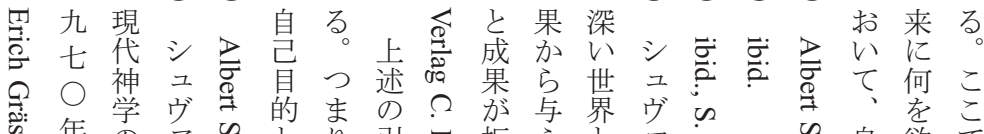

年年 の

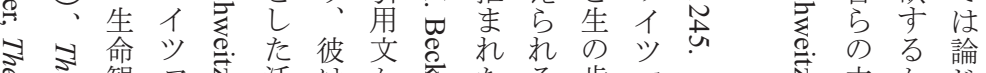

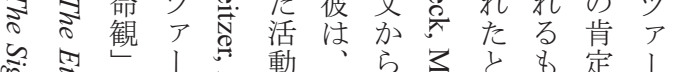

心.

ఏ

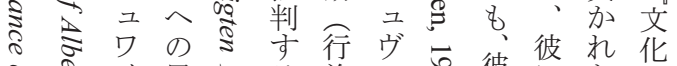

๖

き

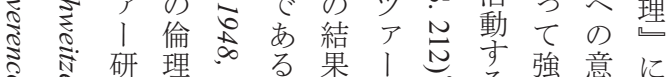

る $仓$ 研理心る。果

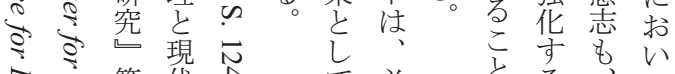

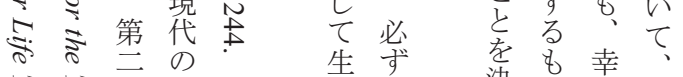

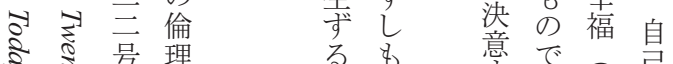

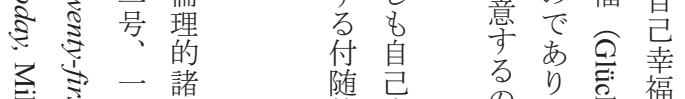

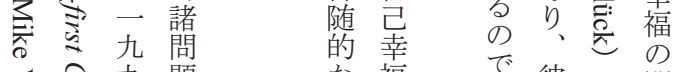

その九題な福离彼と問

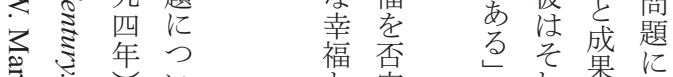

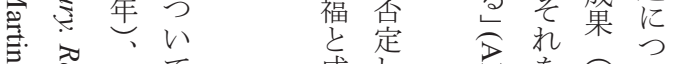

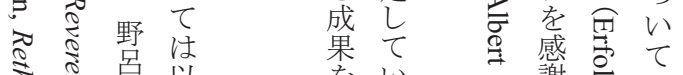

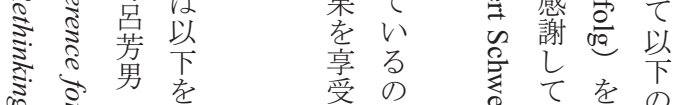

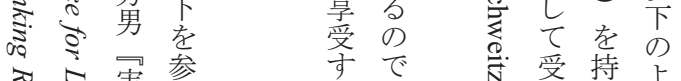

き

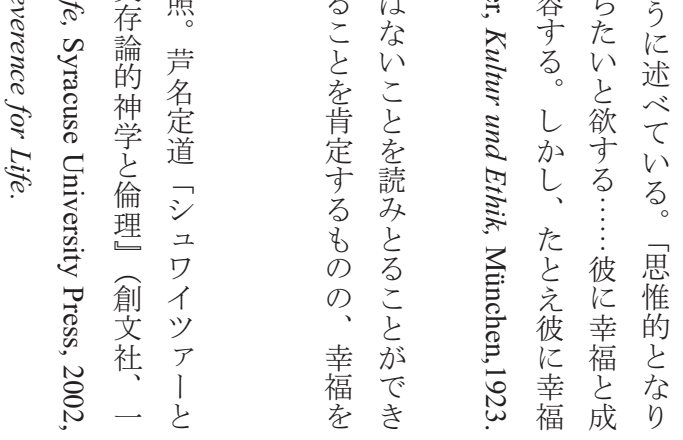

$\begin{array}{lll}\stackrel{0}{N} & \text { あ } & \text { 論 } \\ \text { 立 } & \text { か } & \text { U゙ }\end{array}$

場 る

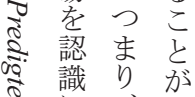

ミ識り、が

๙ お 判き

๖

更浔認が

U 急 䧕

テ 論の ユ

‡で質ヴ

あでア

りはイ

、な ツ

意く

希志は

望質 文

打あ化

いると倫

は言理

楽及に

観し、㧧

でまい

あたて

こ彼 観

とは論

指私悲

摘 の 観

て生涯

い方

る。魚意
惟 志
に
至 


\title{
The Relationship of Ethics and Sermons in the Life of Albert Schweitzer: \\ An Investigation of Reason and Emotion in the Ethics of Schweitzer's Reverence for Life
}

\begin{abstract}
Kentaro Iwai
This paper will look at Albert Schweitzer's Reverence of Life as reflected in his philosophical writings and in his sermons, with the aim of evaluating the meaning of this core idea as expressed in varying contexts. In particular, this paper will examine the elements of reason and emotion and their interrelationship in the process of establishing the ethic of Reverence for Life. The first chapter will focus on the issue of Schweitzer's world view as revealed in the work Culture and Ethics (Kultur und Ethik). It will then lay out a short summary of the process of formation of Schweitzer's ethic of Reverence for life, followed by an examination of the proposition that the worldview based upon the will to live is indeed the only viable worldview.

The critical point of this proposition is the dynamic interrelationship between a naive and optimistic world view and its counterpart, the pessimistic worldview. The ethic of Reverence for Life (an optimistic worldview belonging to a higher stratum) itself must be considered the bridge between these diametrically opposing views.

The second chapter will continue the idea of the ethic of Reverence of Life as the bridge to the dynamic interrelationship of the rational (reason) and the emotional elements. Both reason and emotion are vibrantly reflected in his sermons and are presented with similar constructs. Relying on the Collection of Sermons, 1898-1948 (Predigten 1898-1948), this paper will argue that Schweitzer's thought is not entirely speculative or theoretical but includes an indispensable element of praxis.
\end{abstract}

